\title{
MEMBANGUN BUDAYA LITERASI MEMBACA SISWA MDTA MELALUI BUKU CERITA BERTEMA ISLAM
}

\author{
HAFNI HAFSAH \\ AMIK Tri Dharma Pekanbaru \\ e-mail: hafniedu@gmail.com
}

\begin{abstract}
ABSTRAK
Kegiatan ini merupakan Pengabdian Pada Masyarakat yang bertujuan untuk menyediakan bahan bacaan bagi siswa Madrasah Diniyah Takwiliyah Awaliyah (MDTA) Nurul Jadid 2 di Kota Pekanbaru. Bahan bacaan yang disumbangkan berbentuk buku cetak sebanyak 84 (delapan puluh empat) buku cerita bergambar dan buku bertema Islami yang diharapkan dapat meningkatkan minat dan tingkat literasi membaca siswa. Literasi membaca sangat diperlukan dalam kehidupan seseorang, dimana kebiasaan membaca perlu dipupuk sedari dini, sehingga menjadi suatu budaya. Buku cerita bergambar merupakan bahan bacaan yang menarik bagi anak-anak sekolah, sehingga penulis merasa perlu untuk menyediakan buku-buku tersebut sebagai salah satu bentuk dukungan kepada Program Gerakan Literasi Sekolah. Akses mudah terhadap buku bukanlah hal yang lumrah bagi siswa Madrasah, disebabkan kurangnya sarana dan prasarana seperti perpustakaan di sekolah tersebut. Oeh sebab itu, buku yang disumbangkan dapat dipinjamkan kepada siswa sebagai penambah ilmu dan wawasan serta diharapkan dapat menanamkan budi pekerti yang baik.
\end{abstract}

Kata Kunci: Literasi Membaca, MDTA, Buku Cerita

\section{PENDAHULUAN}

Kebiasaaan membaca sebaiknya dimulai dari sejak usia dini, mengingat anak pada usia ini memiliki keingintahuan yang berkembang akan sesuatu hal yang baru di sekitarnya. Pada masa ini, anak-anak juga berada pada tahap perkembangan fisik dan psikologis yang pesat. Hal ini didukung oleh hasil penelitian yang menyatakan bahwa pertumbuhan intelektual otak anak yang berusia 4 tahun mencapai 50\%, sedangkan pada usia 8 tahun meningkat menjadi $80 \%$, dan menjadi optimal pada usia 18 tahun (Jamaris, 2013). Dengan demikian, hal ini menunjukkan bahwa usia dini sangatlah penting untuk perkembangan anak, sehingga melalui kegiatan membaca diharapkan anak bisa mengetahui dan memahami berbagai macam hal melalui buku ataupun media bacaan lainnya.

Terkait dengan hal di atas, (Lilik Tahmidaten dan Wawan Krismanto, 2020) menyatakan bahwa literasi membaca dengan pemahaman berkaitan erat dengan usaha memahami hal-hal penting dari apa yang dibaca seseorang. Membaca pemahaman atau komprehensif adalah kemampuan membaca untuk mengerti ide pokok, detail penting, dan seluruh pengertian. Pemahaman ini berkaitan erat dengan kemampuan mengingat bahan yang dibaca. Membaca dalam konsep literasi merupakan kegiatan membangun makna, mengaitkan dengan pengalaman hidup sehingga dapat mempraktekannya secara langsung dalam kehidupan (Abidin, dkk., 2018).

Pada tahun 2015, melalui Program Gerakan Indonesia Membaca, yang merupakan program pemerintah bertujuan untuk memberantas generasi nol buku (Kemdikbud, 2016), karena bangsa dengan budaya literasi tinggi menunjukkan kemampuan bangsa tersebut berkolaborasi, berpikir kritis, kreatif, komunikatif sehingga dapat memenangi persaingan global (Kemendikbud, 2017).

Sementara itu data statistik UNESCO yang dilansir tahun 2012 dalam (Jaka Warsihna, (2016), menyebutkan indeks minat baca di Indonesia baru mencapai 0,001, yang berarti bahwa setiap 1.000 penduduk, hanya satu orang yang memiliki minat baca. Sehingga, membiasakan membaca perlu dimulai dari usia muda.

Untuk mendukung program pemerintah yang mengangkat tema literasi pada tingkat sekolah dasar dan menengah pada tahun 2015, dan disamping ketertarikan penulis terhadap hal 
ini, maka penulis menyediakan beberapa buku cerita dan buku agama untuk disumbangkan ke Madrasah melalui kegiatan Pengabdian Pada Masyarakat, yang dilaksanakan di MDTA (Madrasah Diniyah Takmiliyah Awaliyah) Nurul Jadid 2 yang beralamat di JL. Serasi, Perum Delima Puri, Delima, Pekanbaru,

Kegiatan ini diisi dengan pemberian sebanyak 84 (delapan puluh empat) buku (cetak) cerita anak yang bertemakan pada agama Islam ataupun terkait perilaku yang memberikan nilai nilai Islami. Buku yang disumbangkan ini adalah buku-buku bergambar dengan cerita, karena pada umumnya anak-anak suka membaca buku dengan cerita bergambar. Buku cerita bergambar sendiri memiliki berbagai fungsi. Diantaranya adalah membantu anak untuk belajar tentang kehidupan masyarakat yang disajikan secara lebih konkret lewat kata-kata dan gambar ilustrasi (Nurgiyantoro, 2016). Buku yang bergambar memberikan imajinasi visual bagi seorang anak untuk dapat bercerita kembali, mengingat kembali, meskipun anak tersebut belum fasih membaca tulisan yang ada pada buku, dan disamping tentunya ketertarikan terhadap warna -warna yang ada pada buku. Siapa yang tidak suka?

Meskipun demikian, akses anak terhadap buku tidaklah mudah, mengingat harga buku cetak yang barangkali dengan kondisi ekonomi yang sangat sederhana, hal ini tidak berada dalam kebutuhan, atau bisa juga berada diluar jangkuan. Apalagi pada masa pandemic covid 19 saat ini, dimana berberapa orangtua kehilangan pekerjaan ataupun mengalami pengurangan penghasilan. Demikian juga halnya, akses terhadap buku elektronik. Meskipun beberapa harganya lebih murah ataupun gratis, tetapi belum banyak dijumpai, dan untuk mengakses buku ini membutuhkan koneksi internet, yang tentunya membutuhkan pulsa yang harus dibeli.

\section{METODE PENELITIAN}

Pengabdian Masyarakat ini dilaksanakan pada bulan Juli 2021, yang bertempat di MDTA (Madrasah Diniyah Takmiliyah Awaliyah) Nurul Jadid 2 yang berlokasi di Jl Serasi, Perumahan Delima Puri, Delima, Kota Pekanbaru.

Terkait dengan literasi membaca siswa dilakukan dengan membagikan buku bertema Islam ataupun terkait perilaku yang memberikan nilai- nilai Islami sebanyak 84 (delapan puluh empat) buku cerita (cetak). Buku cerita ini disampaikan ke Kepala Sekolah dan disimpan serta dikelola oleh pihak sekolah untuk dapat dipinjamkan kepada siswa siswi sekolah madrasah.

Kegiatan ini juga diisi dengan wawancara dengan Kepala Sekolah beserta salah satu guru di Madrasah tersebut. Kegiatan ini dilakukan di saat diberlakukannya PPKM (Perlakuan Pembatasan Kegiatan Masyarakat) di kota Pekanbaru sehingga tidak memungkinkan untuk melakukan seminar atau pertemuan langsung dengan seluruh siswa madrasah serta tidak mengukur lebih jauh tingkat literasi anak atau siswa Madrasah.

\section{HASIL DAN PEMBAHASAN}

\section{Hasil}

Madrasah Diniyah Takmiliyah Awaliyah Nurul Jadid 2 adalah sekolah non formal setingkat Sekolah Dasar yang didirikan pada tahun 1997 dan resmi mendapatkan izin operasional Kementerian Agama pada tahun 2003. Sekolah ini berada di bawah Yayasan Mesjid Nurul Jadid, yang berada pada lokasi yang sama dengan Madrasah.

Fasilitas yang dimiliki oleh Madrasah hanya terbatas pada 3 (tiga) ruangan kelas dengan perangkat kursi dan meja serta papan tulis, dan 1 (satu) komputer. Adapun jadwal masuk sekolah diatur pada pagi hari dan sore hari, dari kelas 1 (satu) sampai dengan 4 (empat). Jumlah siswa yang ada yaitu 150 orang siswa, dan pada saat pengabdian ini dilaksanakan di bulan Juli 2021 siswa yang mendaftar belum ada. Sedangkan jumlah guru sebanyak 8 (delapan) orang yang semuanya adalah Sarjana. Data yang disampaikan dapat dilihat pada Tabel 1 .. 
Tabel 1. Profil MDTA Nurul Jadid 2

\begin{tabular}{lll}
\hline Fasilitas & Jumlah Siswa & Jumlah Guru \\
\hline $\begin{array}{l}\text { Ruangan kelas, komputer, meja, } \\
\text { kursi, lemari dan buku }\end{array}$ & & 8 orang \\
\hline
\end{tabular}

Mata pelajaran yang disampaikan kepada siswa siswa madrasah adalah Alquran, Hadist, Akidah Akhlaq, Sejarah Kebudayaan Islam, Fiqih, Bahasa Arab, Khot (Kaigrafi). Kegiatan pada hari minggu biasanya dilaksanakan Pendidikan Subuh. Pendidikan subuh ini diantaranya, siswa membaca ayat $\mathrm{Al}$ quran dan menghapalkan serta menyetor hafalan kepada guru, dan guru yang hadir biasanya ada 2 ( dua) orang. Hanya saja pada saat pandemic Covid-19, kegiatan tersebut belum terlaksana secara normal seperti kegiatan sebelum pandemic.

Buku-buku yang disumbangkan kepada pihak Madrasah adalah buku cetak yang berisikan cerita-cerita yang Islami dan membangun akhlak yang baik. Buku yang disumbangkan sebanyak 84 buku. Diantaranya, dapat dilihat seperti gambar di bawah ini.
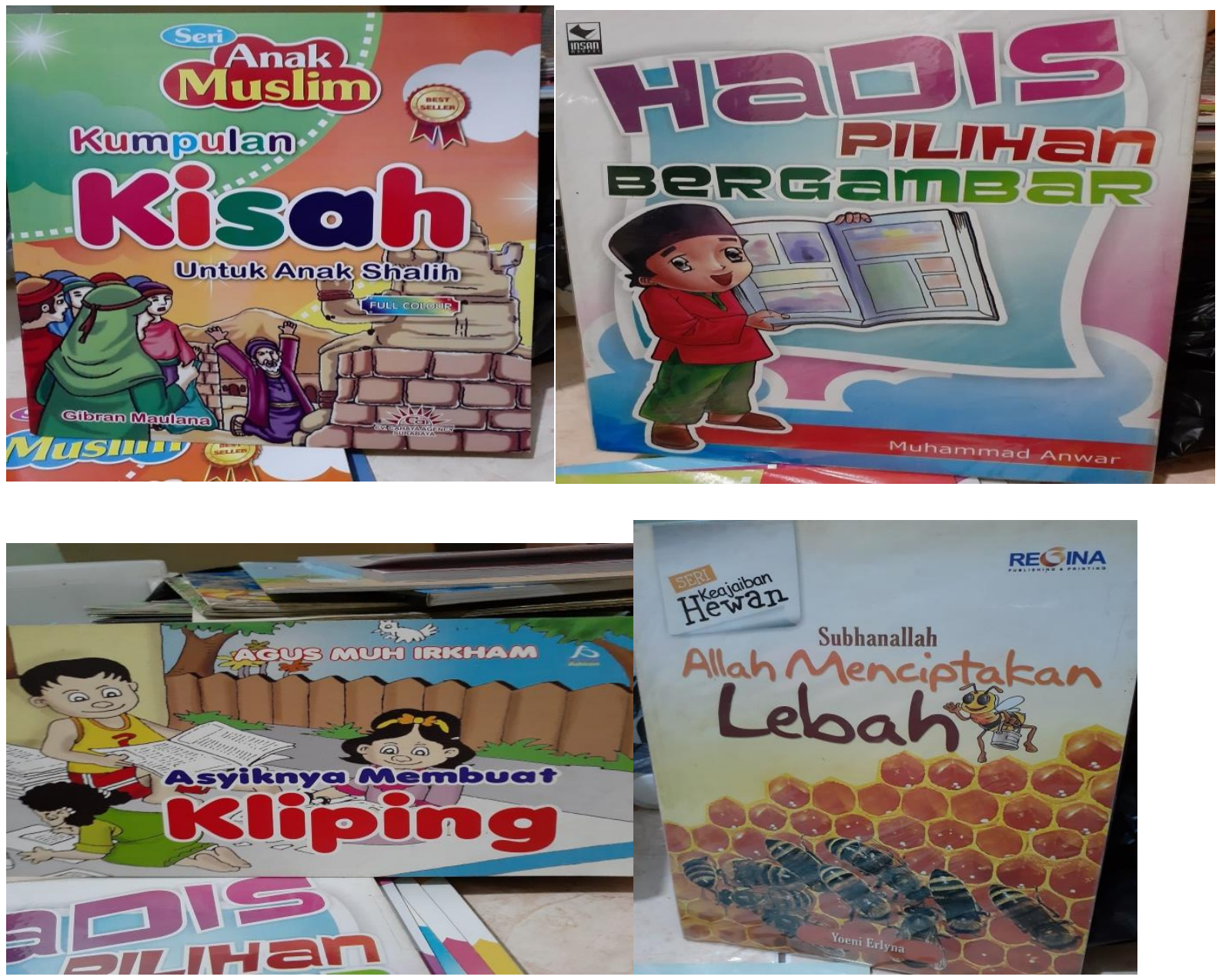

Gambar 1. Beberapa buku bacaan yang disumbangkan

Proses pembelajaran pada madrasah ini menggunakan buku-buku sesuai mata pelajaran yang diajarkan. Model pembelajaran masih mengacu pada kegiatan membaca bacaan lalu menjawab soal dan masih belum memanfaatkan media pembelajaran. 
berikut ini.

Dokumentasi dari kegiatan pengabdian masyarakat ini dapat dilihat melalui foto-foto

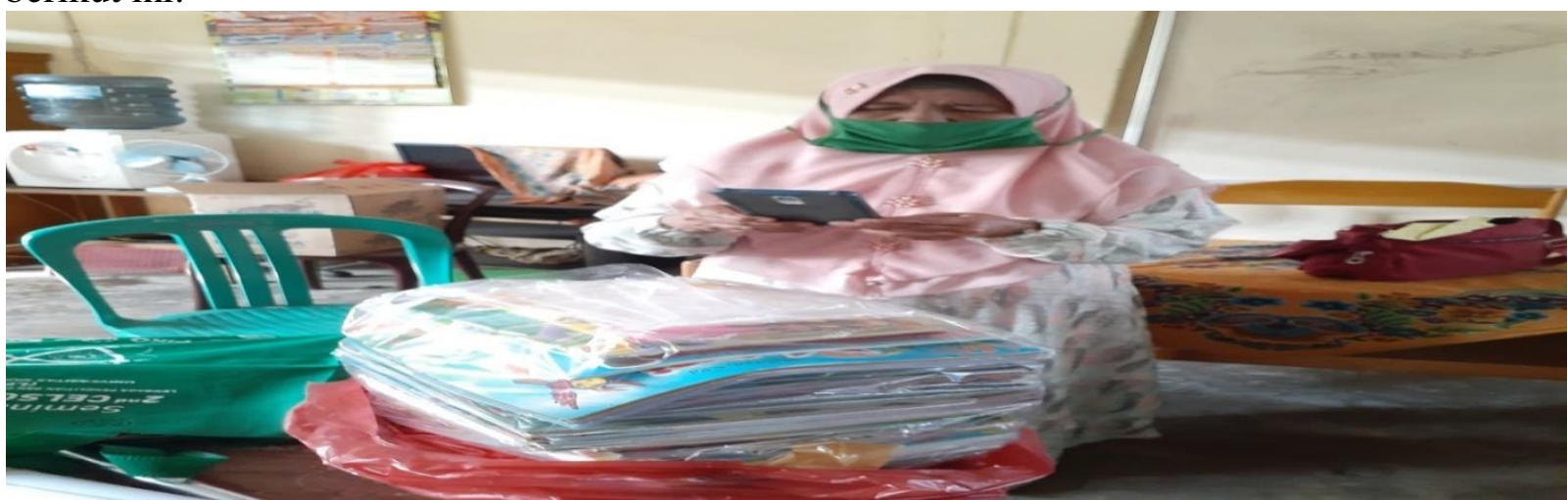

Gambar 2. Foto Kepala Sekolah dan Buku yang disumbangkan

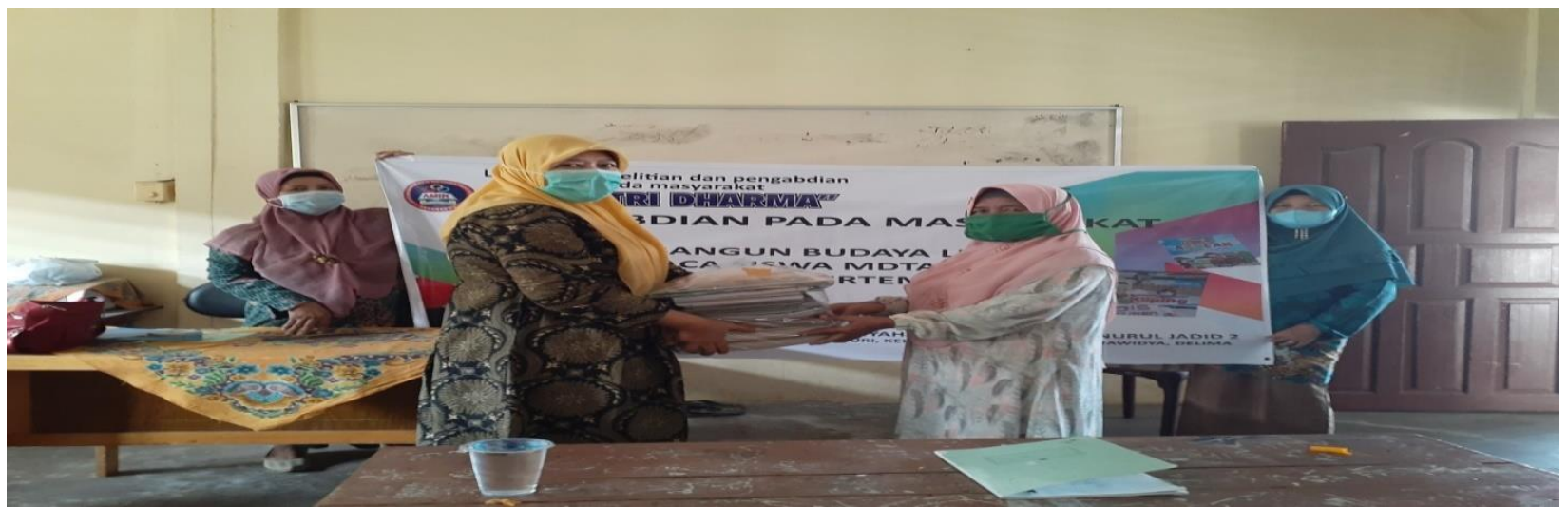

Gambar 3. Foto serah terima buku

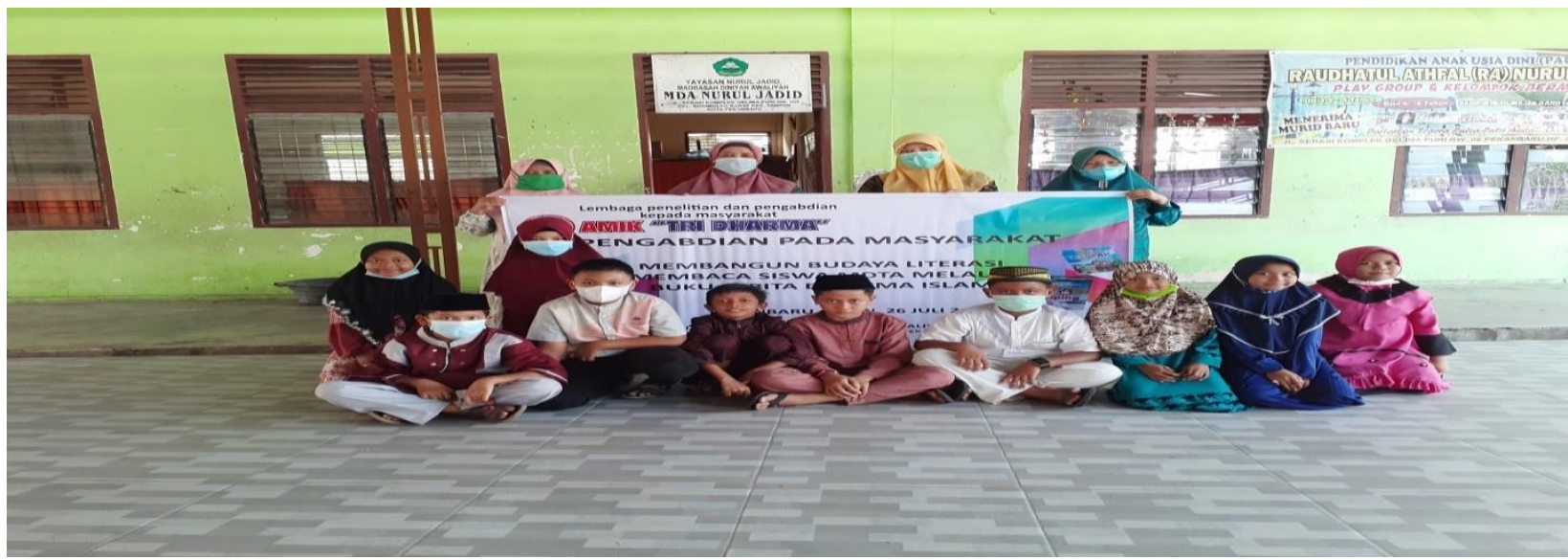

\section{Gambar.4 . Foto Bersama Guru dan Siswa}

Madrasah ini juga menerima sumbangan dari donatur atau beberapa orang yang memiliki kepedulian terhadap pengembangan sekolah, misalnya sumbangan Al Qur'an ataupun fasilitas lainnya.

\section{Pembahasan}

Madrasah Diniyah Takmiliyah Awaliyah (MDTA) merupakan pendidikan keagamaan Islam nonformal sebagai pelengkap bagi siswa SD/MI.sederajat maupun anak usia pendidikan setingkat. Jenjang dasar ini ditempuh selama 4 (empat) tahun dengan sekurang-kurangnya 18 jam

pelajaran dalam seminggu. Pendidikan pada MDTA berbasis masyarakat yang berada di dalam pembinaan Kepala Kantor Kementrian Agama Kabupaten/Kota melalui Kepala Seksi 
Pendidikan Keagamaan dan Pondok Pesantren, atau tingkat organisasi sejenis (Kemenag, 2016).

MDTA Nurul Jadid 2 merupakan salah satu sekolah berbasis Islam yang berada di tengah-tengah pemukiman masyarakat, sehingga mudah untuk di akses oleh siswa atau calon siswa yang ingin bersekolah di tempat ini. Namun dalam hal fasilitas, madrasah ini masih jauh dari cukup. Kekurangan ini dapat dilihat dari tidak adanya ruang guru untuk berdiskusi atau belajar. Kemudian, ruangan kelas yang memerlukan renovasi serta tidak tersedia tempat buku yang memadai atau ruangan perpustakaan untuk membaca buku.

Sekolah ini hanya memiliki satu komputer yang digunakan untuk membantu administrasi sekolah. Di masa sekarang yang serba digital dimana penggunaan komputer di segala bidang, terutama di bidang pendidikan, tentunya madrasah ini juga memerlukan fasilitas yang membantu dalam proses belajar mengajar dengan menggunakan media pembelajaran yang lebih menarik dan kreatif, sehingga menimbulkan semangat siswa untuk lebih memperdalam ilmu pengetahuan. Disamping itu, guru juga bisa memanfaatkannya untuk mencari informasi dan membuat materi pembelajaran yang lebih komunikatif. Apalagi di saat pandemi, proses pembelajaran masih banyak dilakukan dalam jaringan.

Kemudian, buku-buku yang tersedia hanya sebatas buku pelajaran, sehingga siswa tidak memiliki informasi lebih untuk mendukung ilmu yang dimilikinya dalam memahami pelajaran yang diberikan guru. Berdasarkan informasi dari Kepala Sekolah sendiri, bahwa siswa kebanyakan tidak mampu untuk membeli pulsa handphone untuk belajar daring.

Meski demikian, sebenarnya guru bisa saja mengakses buku-buku untuk siswa dari internet, terutama yang disediakan oleh Kementerian Pendidikan dan Kebudayaan pada tingkat Sekolah Dasar/Madrasah ataupun dari e-learning Madrasah Kementerian Agama. Namun, untuk mengakses informasi melalui internet tentunya juga memerlukan dana.

Sementara itu, untuk ruangan dan perangkat yang ada di dalamnya masih bisa difungsikan sebagaimana mestinya. Namun, madrasah tersebut membutuhkan beberapa fasilitas tambahan, terutama untuk mendukung kebiasaan membaca dan pemahaman yang dibaca, sebuah perpustakaan yang berisi beberapa buku yang diperlukan tentunya bukanlah tidak mungkin untuk disediakan. (Kemendikbud, 2017) menyatakan bahwa pintu masuk untuk mengembangkan budaya literasi bangsa adalah melalui penyediaan bahan bacaan dan peningkatan minat baca anak.

Salah satu faktor pendorong rendahnya kemampuan dan budaya baca siswa di Indonesia (Lilik Tahmidaten dan Wan Wawan Krismanto, 2020) yaitu belum maksimalnya sarana prasarana dan pelayanan perpustakaan sekolah sebagai pusat pengembangan kemampuan membaca siswa.

Program Gerakan Literasi Sekolah (GLS) yang dicanangkan pemerintah masih belum memperlihatkan kemajuan yang diharapkan terkait dengan budaya membaca. Peraturan Menteri Pendidikan dan Kebudayaan Nomor 21 Tahun 2015 tentang Penumbuhan Budi Pekerti, salah satunya, mengenai kegiatan membaca buku non pelajaran selama lima belas menit sebelum waktu belajar dimulai. Kegiatan tersebut adalah upaya menumbuhkan kecintaan membaca kepada peserta didik dan pengalaman belajar yang menyenangkan sekaligus merangsang imajinasi. Namun hal seperti ini belum terlaksana di MDTA Nurul Jadid.

\section{KESIMPULAN}

Meskipun tidak dilakukan penelitian lebih lanjut mengenai tingkat literasi pada siswa di Madrasah Nurul Jadid 2, tetapi penelitian yang dilakukan oleh Elizabeth Mayasari dkk . dengan judul Peningkatan Literasi Anak Melalui Buku Cerita Selama Belajar Dari Rumah, memberikan hasil yang positif yang menunjukkan bahwa rata-rata kemampuan literasi anak pada kondisi awal sebesar 40, kemudian setelah mendapatkan kegiatan membaca dan pendampingannya, rata-rata kemampuan literasi anak mengalami peningkatan sebesar 49\%, yaitu menjadi 89. Dengan demikian, untuk memajukan bangsa ini, diharapkan masyarakat dapat berpartisipasi dalam kegiatan-kegiatan yang bisa meningkatkan masa depan anak bangsa 
terutama di bidang pendidikan, khususnya literasi membaca, karena dengan pendidikan yang baik kita bisa menjadi bangsa yang sejahtera.

\section{DAFTAR PUSTAKA}

Abidin, Y., Mulyati, T., \& Yunansah, H. (2018). Pembelajaran literasi: Strategi meningkatkan kemampuan literasi metematika, sains, membaca, dan menulis. Jakarta: Bumi Aksara

Jamaris, M. (2013). Orientasi Baru dalam Psikologi Pendidikan. Penerbit Ghalia Indonesia. Bogor.

Kementerian Agama RI, Direktorat Jenderal Pendidikan Islam, Direktorat Pendidikan Diniyah dan Pondok Pesantre. (2014). Pedoman Penyelenggaraan Madrasah Diniyah Takmiliyah.

Kementerian Pendidikan dan Kebudayaaan. (2017). Panduan Gerakan Literasi Nasional. Jakarta

Mayasari, E.D.,dkk. Peningkatan Literasi Anak Melalui Buku Cerita Selama Belajar Dari Rumah. Paper presented at Prosiding "Ces" (Conference Of Elementary Studies), Universitas Muhammadiyah Surabaya. Retrieved from http://journal.umsurabaya.ac.id /index.php/Pro / article / view /7866

Nurgiyantoro, B. (2016a). Sastra anak: Pengantar pemahaman dunia anak. Yogyakarta: Gadjah Mada University Press

Tahmidaten, L. \& Krismanto, W. (2020). Permasalahan Budaya Membaca di Indonesia (Studi Pustaka Tentang Problematika \& Solusinya). Scholaria: Jurnal Pendidikan dan Kebudayaan, 10 (1), 22-33, from https://doi.org/10.24246/j.js.2020.v10.i1.p22-33

Utami, L. D. (2019). Tingkat Literasi Indonesia di Dunia Rendah, Ranking 62 Dari 70 Negara. Tribun News. Retirieved from: https://www.tribunnews.com/nasional/2021/03/22/tingkat-literasi-indonesia-didunia-rendah-ranking-62-dari-70-negara?page=all

Warsihna, J. (2016). Meningkatkan Literasi Membaca dan Menulis dengan Teknologi Informasi dan Komunikasi (TIK). Kwangsan, 4 (2), 67-80, from DOI: https://doi.org/10.31800/jtp.kw.v4n2.p67--80 